\title{
A Study on China's Marine Rights and Interests and Their Maintenance
}

\author{
LIU Yang and PEI Zhaobin \\ Law School and Coast Guard School, Dalian Ocean University, Dalian 116023, China
}

\begin{abstract}
Marine rights and interests is an important part of national sovereignty, it is also an important part of national interests. At present, the maritime economy and coastline security of China is facing some new situation and challenges. In view of the strategic significance and maritime situation of ocean development, it needs to work out a feasible ocean strategy of China from the need of safeguarding the interests of the whole country urgently. We must establish the maintenance strategies of China's marine rights and interests in order to realize the sustainable development of marine rights and interests.
\end{abstract}

Key words: Marine rights and interests, the United Nations Convention on the law, international cooperation.

\section{Introduction}

The report of the 18th National Congress of CPC puts forward "maritime power", calling for enhanced capacity for exploiting marine resources, protecting the marine environment and safeguarding China's marine rights and interests.

China is both a land power and a sea power. The rise of China includes the rise of ocean. China will move towards powerful national of land power to powerful national of both land and ocean inevitably. This is not only the necessity of connecting China to the world, opening wider to the outside world, but also is the proper meaning to achieve the great renaissance of the Chinese nation. This is not only the inevitable requirement of China to defend the core interests of the maritime territorial sovereignty, but also is the legitimate demands to maintain maritime interests, to ensure the safety of marine channel and the development of marine resources and energy. China is a marine power country and boasts a territorial waters area of nearly 380,000 square kilometres and approximately 3,000,000 square kilometres in the

Corresponding author: LIU Yang, Ph.D., lecturer, research fields: maritime management and urban economy. Pei Zhaobin, Ph.D., associate professor, research fields: maritime security and enforcement and marine law. ocean areas within its jurisdiction. According to UNCLO, the coastal state has sovereignty rights on water under national jurisdiction, such as resource exploitation and utilization, marine scientific research, marine environmental protection and the continental shelf exploitation and protection. However, it is impossible to guarantee the marine rights and interests unless the marine environment is safe in the rapidly changing international relations and frequent disputes. Therefore, it is a very difficult and urgent task to strengthen the construction of marine safety and protect the marine rights and interests.

From the view of historical development, the existence of marine rights and interests does not mean that the state has the sovereignty and jurisdiction of coastal states spontaneously. The national marine rights and interests need to maintain by national power, using the national functions to control and manage the marine objects of national blue territory and sovereignty, in order to ensure the ultimate realizaiton of the national marine rights and interests. The famous Chinese navigator Zhenghe said: "If a country wants to be prosperious, people must protect oceans because oceans can bring us wealth as well as danger and risk." In 1980s, Deng Xiaoping put forward the strategic thoughts of "shelving differences 
and seeking joint development" according to the solution of marine disputes. Xi Jinping, the General Secretary of Central Committee, Chinese Communist Party, pointed out that China's pursuit of its dream of national rejuvenation brings peace and opportunities to the world. That is deeply rooted in the country's constant commitment to peaceful development and its own path ahead. A major player in maintaining both regional and global security and stability, China has been pursuing peaceful growth. Obviously, on the one hand, we always have a peaceful attitude, calling for the harmonious coexistence and neither haughty nor humble; on the other hand, it also reflects the fearless attitude of maintaining marine rights and interests and fighting for each inch of territorial waters.

We must safeguard the national marine rights and interests and make efforts to promote the transition from safeguarding the state's maritime rights to make the type of overall consideration. We love peace and adhere to the road of peaceful development, and we never give up the legitimate rights and interests, or else we could not sacrifice the core interests of the states. Under the two overall situation of stability maintenance and interests guarantee, we adhere to maintain the national sovereignty, security and development interests of unity and keep balance between marine rights and interests maintenance and comprehensive national strength enhancing. We strive to maintain peace and stability, and adhere to resolve the disputes through peaceful and negotiation way. We should prepare to deal with various complex situation and improve the ability of maritime rights and safeguard China's maritime rights and interests firmly.

\section{Definition of Marine Rights and Interests}

Marine rights and interests are the general term of rights and interests of oceans, which manifests as the rights and interests on exploitation, utilization and management of marine resources. According to UNCLO, we believe that the essence of the maritime rights include the ocean utilization and demand of coastal state, the relations between countries and maritime boundary delimitation. The subject of marine rights and interests is the undertaker, practitioner, owner or holder of the ocean rights, which includes states, regional international organizations, international community and mainly refers to sovereign state. The object of marine rights and interests refers to the demanding target of marine rights' subject, which includes inner water, territorial sea, contiguous zone, exclusive economic zone, continental shelf and the high seas.

The "marine land" of China is composed of Bohai Sea, Yellow Sea, East China Sea and South China Sea, three other sea areas are required reasonable division with neighboring countries according to UNCLO except the Bohai Sea of internal waters without controversy. The main problem of the Yellow Sea is the demarcation of the exclusive economic zone between China and Korea. The main issues of the East China Sea are the Diaoyu Islands and the Sino Japanese continental shelf delimitation, and Sino Japanese, South Korea's exclusive economic zone demarcation issues. The main problem of the South China includes islands sovereignty disputes, maritime boundary delimitation and historic fishing rights and other issues.

From the perspective of the historical development experience, maritime rights are the important factor to determine the future and destiny of the country. As far as our country is concerned, marine rights and interests relate to China's territorial sovereignty, resource development, economic development, scientific research and other important areas, which is the key to solve the problems of China's economy, energy, population, environment and so on. It is also the inexhaustible motive force for the continuous development of our country and the important foundation for the realization of China's great rejuvenation. Therefore, we should understand and plan the marine rights and interests, maintain and 
develop the maritime rights with Chinese characteristics further, and promote the construction of harmonious, cooperative, and win-win situation of world's marine rights and interests' new pattern from the strategic perspective.

\section{Compatibility of Marine Rights and Interests}

The ocean which covers $70 \%$ of the earth's area is the hope of world economy development and win-win cooperation. From the perspective of peace and development in today's history, the sea plays an indispensable role in politics, economy, science and technology, energy and other fields. Maritime rights disputes must be the highlight of the world stage. However, the sea is the common wealth of mankind. Building the harmonious sea jointly is different approaches but equally satisfactory results with the ancient Greek philosopher's “harmony will promote justice, beauty and kindness". Sea unity is the congenial way people getting along with the ocean. Countries should build the ocean partnership, protect the ocean environment and be kind to marine ecology while all countries adhere to the ocean development simultaneously. China's Ocean Development Report 2013 points that: China has always adhered to the foreign policy of "Good, Safe and Rich Neighbourliness" and made efforts to create a harmonious and peaceful surrounding environment. The inevitable choice of China's peaceful development path is to grasp the development opportunities with the neighboring countries together.

(1) The premise of compatibility is to maintain marine rights and interests in order to keep territorial integrity. When it comes to marine rights and interests, the first priority is still "guarding the house". We must understand our own territory in order to guard it. We should take care of the territory first, talk about the controversial scope and then turn to the public waters. Concretely speaking, we could develop the ocean resources in a variety of patterns, for example: common area development pattern, exploration and development pattern and out of contact pattern. Because of deepening the ocean area constantly, this needs to cultivate the professional and technical personnel, and strengthen the construction of relevant international system. We should do a good job in marine science and technology innovation planning, and strengthen the core technology and key common technology of the international research and development.

(2) The cardinal of compatibility is to adhere to the policy of "shelving differences and seeking joint development" continuously. China is a peace-loving nation. From the height perspective of national security and social stability maintenance, the Chinese government always adhered to resolve ocean conflicts in a peaceful way in order to achieve a win-win situation. "Cooperation benefits both countries while confrontation can only hurt”. Ocean is the lifeline of China's economy and any conflict will affect the development of the country directly. Although we still could not reach the marine power level to compete with the United States, Japan and other countries, we can only make some concessions on certain issues temporarily. But this policy is just a matter of expediency in the context of the present era. "Sovereignty is a problem that can be negotiated". We must strengthen the maritime sovereignty of China and adhere to the road of peaceful development without giving up the proper rights and interests.

(3) The guarantee of compatibility is based on maritime power. Maritime power is the basic safeguard of marine rights and interests maintenance. We must have a strong maritime strength as a guarantee in order to win the victory in the dispute over marine rights and interests. Maritime power includes not only the developed ocean economy, marine development capability, naval parity but also sound ocean management mechanism and national maritime awareness and other aspects. We should make efforts to build our country from the big ocean 
country into maritime power to safeguard China's maritime sovereignty. Firstly, we should improve the ability of ocean development and expand the field of maritime development in order to make the ocean become the new economic growth point. Secondly, we ought to increase investment in science and technology, and increase the scientific research of sea and navy. Build the high-tech armed naval force to counter the international threat. Thirdly, we should introduce relevant laws and regulations in order to safeguard maritime sovereignty resolutely in terms of ocean management. Although UNCLO is known as the "charter of marine", it stipulates the marine political rights and interests of all countries in the world in details. This has laid the legal foundation and the basic mechanism for the maintenance and the dispute settlement of marine rights and interests. But there is no clear and uniform standards of rules and practices according to the establishment content of UNCLO. Its insufficient is obviously not enough to rely on the provisions of the law to implement the maintenance of marine rights and interests. Finally, we should not only improve the maritime awareness of nation, the concept of the ocean from domestic, but also learn the historical experience of world maritime power development. And we should continue to study and summarize the world cases of maritime delimitation, island contention and division and sharing of fishery resources. "Know the sea and love the sea, make use of the sea while manage the sea, prosper the sea while study the sea". We will make efforts in marine awareness, marine ecology, marine development, marine industry, marine technology and marine culture.

\section{Dauntless of Marine Rights and Interests}

China has faced with a very complicated situation in the maintenance of marine rights and interests. The contradictions and struggles are very sharp. There is still controversy in the Yellow Sea, East China Sea and the South China Sea in three areas and eight neighboring countries from the North to South. As we can see that China's maritime power maintenance is a difficult task with grim reality from the event of Diaoyu Islands and Huangyan Island. The maintenance of maritime power is a struggle related to the survival and development of Chinese nation, which is also the combat to safeguard national sovereignty and territorial integrity. We have always uphold the peaceful diplomacy of the great powers and adhere to the path of peaceful development without giving up the legitimate rights and interests. "Sovereignty belongs to me" is the basic premise to solve maritime disputes and we should fight for each inch of maritime power problems.

(1) The military strategy is to establish the confidence of fighting for victory. The problem of maritime power is the national marine rights and interests struggle to maintain and develop sea power. We must build a modern navy team with powerful deterrent and combat capability in order to provide strong support and powerful backup for marine rights and interests maintenance and expanding. Therefore, we should increase the investment of maritime military theory and focus on the development of air defense in order to realize the modernization of the Navy and air force. Use high technology to narrow the space gap and it will safeguard China's offshore islands sovereignty and marine rights and interests protection. It will build up the confidence to become the maritime power.

(2) The economic strategy is to improve the ability of marine resources development in order to make the maritime economy become the new growth point. Maritime economy is the important support for the maintenance and development of maritime power, and it is an important support for the construction of marine power. Promote the marine development from resource consumption into green sustainable type through scientific and technological progress vigorously. Promote the center of marine development by expanding from the offshore to deep sea. Focus on 
the country's financial and high-tech power to develop the disputed waters in priority. Improve the contribution rate of marine science and technology to marine economy continuously and ensure that "make good use of your own and share the common".

(3) The political strategy is to deepen the international exchanges and cooperation, then understand and plan the marine power from a strategic perspective. From the current situation, it is a long-term task to protect and struggle for the marine rights and interests. China should promote dialogue and cooperation with neighboring countries actively, and establish the sound system of dialogue and consultation about maritime affairs with the relevant countries. Participate in the international marine rules widely in order to grasp the initiative in the development and utilization of marine resources, the guarantee of national interests abroad and the discourse right of international maritime affairs. This will provide basic rules for the construction of maritime power.

(4) The management strategy is to integrate the maritime law enforcement forces and establish an early warning mechanism for the maritime safety emergency. Currently China needs to build a unified maritime law enforcement team urgently, which includes the navy, transport fleet, fishing fleet, marine scientific research and the maritime administrative law enforcement team. This can reflect the ability of national marine research, and the ability to exploit and defend the maritime security and maritime rights. At the same time, the marine monitoring and warning mechanism should be set up including monitoring and forecasting, emergency rescue, organizational network and emergency measure. Deal with the relevant maritime security threats and accident disputes timely and reduce the loss to the minimum.

(5) The legal strategy is to strengthen the construction of marine laws and regulations system, and establish the special marine laws and regulations such as Ocean Basic Law as soon as possible. It can strengthen the legal support for the claim of China's marine rights and interests. China should attach importance to the study of the United Nations Convention on the Law of the Sea and formulate the special law aiming at safeguarding China's marine rights and interests protection, such as: Ocean Basic Law, Law on Territorial Waters, Laws on Exclusive Economic Zones, Laws on Continental Shelf. Accelerate the construction of marine legislation, law enforcement and judicial to explicit the basic principles of marine rights and interests protection, subject of liabilities and the punishment measures for the related violations of law. There must be laws to go by, the laws must be observed and strictly enforced, and lawbreakers must be prosecuted.

\section{The Development of Marine Rights and Interests}

As China moving towards the world powers steadily, the demands for the ocean are more dependent and increasing. When China speeds up to the oceans and expands the national interests constantly, it will converge and overlap the interests with other countries inevitably. This will require a new examination of the ocean situation and marine rights and interests maintenance from the new normal perspective. It needs to create a harmonious strategy of marine environment and promote the construction of the harmonious world in order to safeguard the great rejuvenation of the Chinese nation.

Facing with the opportunities and challenges, China should seek bigger benefits according to UNCLO and some other international laws. Meanwhile, it is also emphasized that we should build a harmonious marine environment and adhere to keep the balanced development of the ocean peacefully. With the development of technology and human society, a new era of ocean has already come. Do not seek marine hegemony and construct the new type marine power of "strong and not hegemonic".

Napoleon Bonaparte once said that "China is a 
sleeping lion," and "when China wakes up, the world will shake." Many people only understand it from the surface, who reckons that China will pose threats to the world once awakened. In fact, the lion of China has awoken, but what the world sees now, is a peaceful, amiable, civilized lion. China's vivification brings peace, friendship and common development to the world. The world is shivering with China's image in dealing with international affairs as a responsible big country. The world is shivering with China's new concept of peaceful coexistence and common development. The world is shivering with China's strategic blueprint of the power is the key, the periphery is the first, the developing country is the foundation and the multilateral relationship is the arena. Just as Xi Jinping says: "The beautiful Chinese dream needs peace, only peace can realize the dream. For a long time Chinese people have longed for world peace, and taken it as an obligation. We have been in wars and recessions, and we understand how precious peace is. China wishes to work with all countries in the world to bring peace to the globe, as well as protecting and enjoying it. According to history, realizing the Chinese dream would bring opportunities rather than threats, peace rather than turmoil to the world. It will help the world make progress in various aspects.”

China will strengthen the strategic partnership relations with neighboring countries actively. China will strengthen the cooperation with countries in various areas of the world with the development idea of harmonious marine. China is willing to firmly grasp the correct direction, share weal and woe and help each other with the other countries in the world. We are firm in our resolve to uphold China's sovereignty, security and development interests. All sides should share the same vision of the relationship, communicating honestly to seek common points while reserving differences. We should support each other in maintain national sovereignty and security as well as other core interests. We should also engage in strategic dialogue, deepening cooperation, and deal with differences properly. We need to make the relationship more strategic, more stable and more transparent in order to further preserve our common interests. Great achievements are made of dreams, opportunities and hard work. And now Chinese people are chasing the Chinese Dream: the dream of a strong nation, and the great rejuvenation of the Chinese people.

\section{Conclusion}

The same strategic choice and path of all the powerful nations is towards the sea. Today every country pays more attention to the ocean's strategic position and significant value than any time before. The situation of China's maritime rights will be more severe and complex. In the new round of the ocean's competition, how to not only defend China's maritime territory, safeguard our country's marine rights and interests but also deal with the relationships with neighboring countries and maintain regional peace and stability? This is an important issue worth of considering and dealing with. We suppose that: harmony is our attitude, development is our concept, win-win cooperation is our destination, and deep blue is the color of the Chinese nation.

\section{Acknowledgements}

This work was supported by Education Department of Liaoning funded project (W201608,W201607), International Education Scientific Research Project of Liaoning Province (16NGJ044), China Association of Marine Affairs funded project (CAMAJJ201504), Dalian Social Science Association funded project (2015dlskzd109), Liaoning Marine Law Research Association funded project (2016hyfxyjh05).

\section{References}

[1] Guo, Y. 2005. "Marine Rights and the Construction of Ocean Order.” Xiamen University Law Review (2).

[2] Gui, J., and Fan, X. T. 2010. "Research on National Legal 
Regime of Marine Rights and Interests.” Ocean Development and Management (1).

[3] Chen, S. Y. 2011. "The Protection of Marine Rights and Interests and Its Practice in China under the Comparative Law.” Seeker (5).

[4] Ma, J. C. 2014. "Exploration on the Protection of Marine Rights and Interests of China.” Legal System and Society (8).

[5] Yu, S. W. 2008. "On the Sea Security Being the Premise of Safeguarding the Sea Rights.” Public Administration
\& Law (8).

[6] Pei, Z. B., and Wang, L. L. 2016. “The Nomocracy Pursuit of the Maritime Silk Road-On Legal Guarantee of State's Marine Rights and Interests.” Journal of Shipping and Ocean Engineering (6).

[7] Li, M. C. 2007. Maritime Rights and Interests and the Rise of China. Beijing: Ocean Press.

[8] He, L. 2010. “China’s Marine Rights and Interests and Their Maintenance.” Journal of Ideological \& Theoretical Education (10). 